\title{
Czy kultura i tradycje narodowe tracą na znaczeniu? Raport z badań porównawczych nad postawami i ich analiza w kontekście wartości
}

\begin{abstract}
The research examines the attitudes to national culture and traditions, and a system of values. Analyses were conducted in 2003 (a sample of 325 students), and in 2008 (a sample of 379 students), and in 2013 (a sample of 368 students). It was assumed that (1) there are differences between three groups in acceptance of attitudes and (2) that attitudes to national culture and tradition depend on the value system. The Rokeach's concept provides the theoretical background. The results of research allow stating that most students underline the significance of national heritages. The lowest acceptance of national heritage was observed in 2008. Moreover, attitudes depend on the value system: a positive attitude to culture and traditions of the own nation is connected with the higher preference of collective values, whereas the acceptance of cultural integration with the western countries is linked with individual values.
\end{abstract}

\section{Keywords:}

attitude to national culture and tradition, value system, individualism collectivism

1 Mirosława Czerniawska, Katedra Ekonomii i Nauk Społecznych, Wydział Inżynierii Zarządzania, Politechnika Białostocka w Białymstoku, Polska, m.czerniawska@pb.edu.pl. 


\section{WPROWADZENIE}

Mentalność ukierunkowuje sposób rozumienia rzeczywistości: to, w jaki sposób człowiek opisuje świat zastany, oraz to, jaką idealną wizję jego tworzy. Jeżeli uwagą objęta jest mentalność mająca swoje źródło w kulturze, to określa się ją mianem „kultura subiektywna”. W jej skład wchodzą takie elementy, jak: kategorie, związki, postawy, przekonania, cele, atrybucje, oczekiwania, normy, role, zasady, definicje Ja, stereotypy, ideały, wartości, standardy (estetyczne, ekonomiczne, społeczne, polityczne, naukowe, religijne), teorie, mity, ideologie, religie oraz aprobowane wzorce zachowań. Ludzie uspójniają te elementy i organizują je wokół jakichś tematów. Powstają dzięki temu syndromy kulturowe wyznaczone przez korelacje pomiędzy składnikami subiektywnej kultury (Triandis, 1996; por. Czerniawska, 2010).

Syndromem kulturowym, który cieszył się szczególnym zainteresowaniem w ciągu ostatniego ćwierćwiecza w Polsce, jest „kolektywizm - indywidualizm” (np. Daab, 1990; Reykowski, 1992; Jarymowicz, 1999; Miluska, 2005; Cybal-Michalska 2006; Bokszański, 2007). Kolektywizm opisywany jest przez Triandisa (1996) jako zbiór elementów kultury subiektywnej koherentnych z założeniem, że jednostki są przede wszystkim członkami grupy, indywidualizm z kolei - jako zbiór elementów kultury subiektywnej koherentnych z założeniem, że jednostki są istotami autonomicznymi. Za pomocą tych pojęć zobrazowane są różnice w mentalności, które opierają się na kryterium relacji „Ja - grupa”. Fakt, czy centrum psychologicznego pola stanowi Ja, czy też grupa do której jednostka należy, ma poważne konsekwencje: jest podstawą tworzonej w umyśle człowieka koncepcji świata społecznego i koncepcji ludzkiej istoty, koncepcji więzi społecznych i zasad podejmowania aktywności (Reykowski, 1992). Najogólniej mówiąc, jest to wizja tego, jak powinien być „urządzony” świat społeczny i ku czemu powinni dążyć ludzie. Pytanie o wizję świata społecznego, jak również o dominujące wśród ludzi wzory motywacji, wydaje się szczególnie istotne w okresie przemian polityczno-ekonomicznych. W naszym kraju przybrało ono następującą postać: czy efektywne funkcjonowanie w nowym ładzie ustrojowym wymaga przeobrażeń mentalności społeczeństwa „ku indywidualizmowi”? Mentalność indywidualistyczną uznano za tę, która „pasuje” do nowoczesnego społeczeństwa, demokracji liberalnej i gospodarki wolnorynkowej, mentalność kolektywistyczną - za tę, która jest reliktem minionego ustroju, utrudniającym proces przemian ustrojowych (szerzej na ten temat w: Czerniawska, 2010).

W skład syndromu „kolektywizm - indywidualizm” wchodzi wiele zmiennych, wśród których dużą wagę przypisuje się wartościom. Na podstawie analizy 
ich wskaźników opracowano mapę kulturowego zróżnicowania społeczeństw (Schwartz, 2003). W charakterystyce porównawczej kultur uwzględniano przede wszystkim kryterium interesów, którym wartości służą. Wartości służące interesom innych ludzi leżą u podstaw kształtowania się mentalności kolektywistycznej, wartości skoncentrowane na własnej osobie - kształtowania się mentalności indywidualistycznej. Okazało się na przykład, że orientacja kolektywistyczna w większym stopniu charakteryzuje społeczeństwa zamieszkujące Europę Środkowowschodnią niż społeczeństwa zamieszkujące Europę Zachodnią (Schwartz, Bardi, 1997). Ujawnia się to zwłaszcza wtedy, gdy wśród wartości zorientowanych kolektywistycznie (społecznie) i indywidualistycznie (jednostkowo) uwzględni się wymiar „konserwatyzm - otwartość na zmiany”. Schwartz wykazał, że kraje Europy Środkowowschodniej w porównaniu z krajami Europy Zachodniej cenią bardziej wartości konserwatywne (wchodzą one w skład orientacji kolektywistycznej). Wśród krajów naszego regionu z kolei jeden z najwyższych wskaźników wartości konserwatywnych uzyskała Polska (Schwartz, Bardi, 1997, za: Lewicka, 2005; w publikacji znajduje się szersza charakterystyka zróżnicowania wartości w kategoriach wymiarów oraz typów). Wymiar „konserwatyzm - otwartość na zmiany” odzwierciedla konflikt między dążeniem do stabilności i kultywowaniem tradycji (submisyjne ograniczenie Ja) a dążeniem do zmian i wysokim wartościowaniem autonomii, przejawiającej się w niezależności myślenia i działania. Ludzie preferujący wartości konserwatywne są przywiązani do kulturowych i religijnych obyczajów (typ wartości: tradycja), powstrzymują się od społecznie nieakceptowanych działań (typ wartości: przystosowanie/konformizm), zabiegają o stabilność i ochronę społeczeństwa oraz związków z innymi ludźmi, jak również bezpieczeństwo własnej osoby (typ wartości: bezpieczeństwo) (Schwartz, 1996; szerzej na ten temat w: Czerniawska, 2010). Wyższy poziom akceptacji wartości konserwatywnych powinien ukierunkować szczególny sposób myślenia o narodzie, jego dziedzictwie kulturowym, tradycji i historii oraz symulować dążenie do zachowania tego, co już zostało „ustanowione”.

Należy jednak zauważyć, że ludzie nie zawsze odzwierciedlają w swoim systemie wartości pełną charakterystykę aksjologiczną kultury. Jeszcze większej rozbieżności można spodziewać się w trakcie zmian ustrojowych, kiedy człowiek styka się z ideologiami opartymi zarówno na starym, jak i nowym porządku aksjologicznym. System wartości społeczeństwa staje się wtedy heterogeniczny i odzwierciedla wyraźniej kolektywistyczne bądź indywidualistyczne nastawienia jednostek lub grup społecznych. Jeżeli uwzględni się fakt, że priorytety w sferze wartości określają postawy i ukierunkowują ich organizację, to można również spodziewać się - w zależności od pozycji wartości kolektywistycznych 
i indywidualistycznych w systemie - silnej dyferencjacji tych postaw. Skutkuje to odmiennymi przekonaniami na temat tego, jak świat społeczny powinien być „urządzony”.

W niniejszym artykule zaprezentowano wyniki badań, które pozwolą odpowiedzieć na pytanie, czy zróżnicowanie systemów wartości w wymiarze „kolektywizm - indywidualizm” (relatywnie wyższe wskaźniki preferencji wartości kolektywistycznych lub indywidualistycznych) związane jest z postawami respondentów (polskich studentów) wobec polskiej kultury narodowej i tradycji. Kultura narodowa stanowi - według Kłoskowskiej (1996) - szeroki i złożony układ sposobów działania, norm, wartości, wierzeń, wiedzy i dzieł symbolicznych, który przez jakąś zbiorowość społeczną uważany jest za własny, jej w szczególności przysługujący, wyrosły z tej tradycji i historycznych doświadczeń oraz funkcjonujący w jej obrębie. Jest więc dziedzictwem, które należy zrozumieć, obdarzać szacunkiem i zinternalizować w takim stopniu, aby mieć poczucie ekskluzywnej tożsamości narodowej. Problem ten wydaje się istotny z uwagi na szybki przepływ wzorów kulturowych z Zachodu. Ich przyjęcie może podważyć poczucie ciągłości i wspólnotowych więzi, poczucie dumy związanej z osiągnięciami własnego narodu.

W celu zdiagnozowania, jakie znaczenie przypisują respondenci kulturze własnego narodu w relacji do kultury zachodniej i czy - ich zdaniem - zmiany ustrojowe powinny uwzględniać „zakorzenienie” w tradycji, przeprowadzono trzy badania, tj. w roku 2003, 2008 i 2013 (wyniki dwóch pierwszych badań opublikowane zostały w: Czerniawska, 2010, 2013). Pomiary postaw w dystansie pięcioletnim, przy użyciu tych samych narządzi badawczych, pozwalają prześledzić ich zmianę. Osobami badanymi byli studenci tych samych uczelni wyższych, zaś trzy próbki badawcze miały zbliżoną charakterystykę (por. opis zamieszczony niżej). W trakcie badań diagnozie poddane zostały również systemy wartości. Umożliwiło to sformułowanie odpowiedzi na pytanie, czy postawy wobec kultury i tradycji narodowych mają uwarunkowania aksjologiczne. A bardziej precyzyjnie: jakie postawy wiążą się wartościami będącymi wykładnikiem mentalności kolektywistycznej (orientacja kolektywistyczna w systemie wartości), a jakie - z wartościami będącymi wykładnikiem mentalności indywidualistycznej (orientacja indywidualistyczna w systemie wartości). Należy podkreślić, że wartości i postawy ukierunkowują sposób myślenia o świecie, ocenę występujących w nim zjawisk i leżą u podstaw inicjacji zachowań. Pierwsze z nich - będąc przekonaniami bardziej abstrakcyjnymi i trwałymi - ukierunkowują organizację postaw, pozwalają je przewidywać i uzasadniać. Te z kolei mają bardziej konkretny charakter i są podstawą wartościowania określonych obiektów. Im bardziej postawa powiązana jest z wartościami, tym trudniej ją zmienić. Jednocześnie z wartościami w więk- 
szym stopniu powiązane są postawy silne. Ich siła uwarunkowana jest tym, że „opierają” się one na wartościach (Rokeach, 1980; Gilchrist, por. Seligman, Katz, 1996; Maio, Olsen, 1998; por. Czerniawska, 2010).

Podjęcie tej problematyki badawczej wynika z zainteresowania zmianami mentalności społeczeństwa polskiego, które są konsekwencją przeobrażeń ustrojowych w naszym kraju. Dotyczyły one zasadniczo sfery polityki i gospodarki, ale odnosiły się również do kwestii kultury i tradycji narodowych. Część społeczeństwa opowiadała się i nadal opowiada za tradycjonalizmem, część - za uniwersalizmem i jak najszybszym dołączeniem do Zachodu. Od 2004 roku, a więc momentu wejścia Polski do Unii Europejskiej, status kultury narodowej stał się mniej jednoznaczny, ponieważ wzrosła rola „europejskości” w kształtowaniu tożsamości społeczeństwa polskiego. Jaki jest zakres tego procesu i czy ma on postępujący charakter? Czy - jak uważają Marody i Giza-Poleszczuk (2004) - przejście do nowej formy organizacji społecznej wiąże się z masowym wykorzenieniem jednostek z ich dotychczasowych wspólnot?

\section{PROBLEM BADAWCZY I METODA BADAŃ}

W niniejszym badaniu starano się ustalić, jakie znaczenie przypisywane jest kulturze i tradycjom narodowym. Czy następstwem procesu zmian ustrojowych i integracji europejskiej jest wzrastająca akceptacja kultury zachodniej? Aby odpowiedzieć na to pytanie, dokonano trzykrotnego pomiaru postaw. Założono, że obniża się wśród studentów - porównanie grup badawczych z roku 2003, 2008 i 2013 - znaczenie przypisywane rodzimej kulturze i tradycji (hipoteza 1), co uznać można za efekt szeroko rozumianego otwarcia na Zachód.

W następnej kolejności ustalono, jaką rolę we wskazanych postawach odgrywają wartości. Wartości wchodzące w skład orientacji kolektywistycznej odzwierciedlają dążność do zakorzenienia się w grupie i skłonności konformistyczne. Nastawione są na harmonię, stabilność i utrzymanie tego, co „ustanowione”. Wiązać się zatem powinny ze skłonnością kultywowania kultury i tradycji narodowych. Wartości wchodzące w skład orientacji indywidualistycznej z kolei stymulują osiągnięcia i rozwój, determinują otwartość na zmiany, wiążą się z wewnątrzsterownością, autonomią w myśleniu i działaniu. Przywiązanie do takich wartości czyni bardziej prawdopodobną akceptację przeobrażeń w warstwie kulturowej (hipoteza 2).

W niniejszej pracy przyjęto za Rokeachem (1973) sposób rozumienia wartości. Jest ona utożsamiana z pojęciem abstrakcyjnym, które jako kryterium ogólne wyznacza preferencje celom oraz środkom realizującym te cele. Autor opisał 
model, w którym funkcjonuje relatywnie niewiele wartości i wiele tysięcy postaw. Oba konstrukty są definiowane w kategoriach przekonań, pomiędzy którymi zachodzi formalny i funkcjonalny związek. Wartości odnoszą się do pojęć ogólnych, postawy - do specyficznych obiektów, zjawisk czy osób. Wartości są silniej powiązane z koncepcją Ja, stanowią rodzaj centralnych dyspozycji osobowościowych, ukierunkowują postawy i decyzje behawioralne (szerzej na ten temat: Czerniawska, 2010).

Grupa badana. W badaniu wzięły udział 1072 osoby, z czego 325 (30,32\%) w 2003 roku, 379 (35,35\%) - w 2008 roku i 368 (34,33\%) - w 2013 roku. Trzy grupy były ujednolicone pod względem:

- kierunku kształcenia: około 50\% badanych stanowili studenci pedagogiki Uniwersytetu w Białymstoku i około 50\% badanych - studenci zarządzania Politechniki Białostockiej;

- trybu kształcenia: studia stacjonarne;

- poziomu kształcenia: studenci pierwszego, drugiego i trzeciego roku;

- płci: przewaga liczbowa kobiet (około 80\%);

- wieku: około 90\% badanych stanowili studenci w wieku 20-21 lat.

Tabela 1. Charakterystyka grupy badanej

\begin{tabular}{ccccccc}
\hline \multirow{2}{*}{$\begin{array}{c}\text { Wiek } \\
\text { (w latach) }\end{array}$} & \multicolumn{2}{c}{ Badanie z 2003 roku } & \multicolumn{2}{c}{ Badanie z 2008 roku } & \multicolumn{2}{c}{ Badanie z 2013 roku } \\
\cline { 2 - 7 } & liczebność & odsetek & liczebność & odsetek & liczebność & odsetek \\
\hline 24 & 6 & $1,85 \%$ & 10 & $2,64 \%$ & 3 & $0,82 \%$ \\
\hline 23 & 7 & $2,15 \%$ & 10 & $2,64 \%$ & 12 & $3,26 \%$ \\
\hline 22 & 22 & $6,77 \%$ & 25 & $6,60 \%$ & 30 & $8,15 \%$ \\
\hline 21 & 242 & $74,46 \%$ & 282 & $74,40 \%$ & 283 & $76,90 \%$ \\
\hline 20 & 48 & $14,77 \%$ & 52 & $13,72 \%$ & 40 & $10,87 \%$ \\
\hline
\end{tabular}

Źródło: Opracowanie własne.

Uwzględniając przedstawioną powyżej charakterystykę trzech grup badawczych, sądzić można, że cechuje je zbliżony zakres wiedzy na temat rzeczywistości społeczno-politycznej, porównywalny poziom intelektualny, podobne - związane z kierunkiem studiów i okresem rozwojowym - zainteresowania, jak również zbliżone doświadczenia interpersonalne (charakter relacji społecznych).

Narzędzia badawcze. Postawy były diagnozowane za pomocą par twierdzeń, które stanowią alternatywne przekonania. Zadaniem osób badanych był wybór jednej z dwóch opcji, tej która w większym stopniu odzwierciedla poglądy jednostki 
w stosunku do rozważanego problemu. Twierdzenia te stanowią zmodyfikowaną treściowo wersję narzędzia zamieszczonego w pracy pod redakcją Reykowskiego (1993) Wartości i postawy Polaków a zmiany systemowe.

\section{POSTAWA A}

1. Musimy wyjść z zaścianka tradycji i naszych polskich opłotków. Polska musi jak najszybciej dołączyć do Zachodu.

2. Polska musi zostać Polską i trzeba bacznie uważać, aby importowana nowoczesność nie zniszczyła naszej kultury i tradycji narodowych, bez których nie bylibyśmy Polakami.

\section{POSTAWA B}

1. Rozpatrywanie odrębności kulturowej brzmi śmiesznie. Jeżeli chcemy, by nas poważnie traktowano, to musimy przyjąć wzorce Zachodu.

2. Poczucie odrębności kulturowej wyraża nasz szacunek do samych siebie. „Małpując” bezmyślnie innych nie zyskamy wcale w ich oczach.

Preferencje wartości określone zostały za pomocą Skali Wartości Rokeacha w wersji wymagającej rangowania (Brzozowski, 1989). Autor wyselekcjonował osiemnaście wartości ostatecznych i osiemnaście wartości instrumentalnych, umieszczając je na dwóch odrębnych skalach. Osoby badane zobowiązane były do uporządkowania wartości przez przypisywanie im odpowiednich rang.

$\mathrm{Z}$ punktu widzenia sformułowanego problemu badawczego konieczne jest sprecyzowanie, jakie wartości kryją się w konstelacji „kolektywizm - indywidualizm” (zasady klasyfikacji wartości przedstawiono w innym miejscu, por. np. Czerniawska, 2010).

Ze Skali Wartości Rokeacha uznano za kolektywistyczne wartości związane z:

- ochroną dobra wszystkich ludzi oraz tych, z którymi jednostka wchodzi w bezpośrednie interakcje (dobrostan grupy, do której jednostka należy): „pokój na świecie” (o8), „równość” (o12), „pomocny” (i13), „uczciwy” (i15), „wybaczający” (i18), „kochający” (i4), „odpowiedzialny” (i8);

- bezpieczeństwem grup tożsamościowych i poszanowaniem tradycji/religii: „bezpieczeństwo rodziny” (o2), „bezpieczeństwo narodowe” (o1), „zbawienie” (o17);

- wyważonymi poglądami społecznymi, harmonią intrapersonalną i interpersonalną: „mądrość” (05), „równowaga wewnętrzna” (011), „opanowany” (i10), „czysty” (i2) „,uprzejmy” (i16), ,posłuszny” (i14), „dojrzała miłość” (o3), „prawdziwa przyjaźń” (o9). 
Za indywidualistyczne uznano wartości związane z:

- statusem społecznym, prestiżem i sukcesem osobistym (w tym również materialnym): „uznanie społeczne”, „poczucie własnej godności”, „poczucie dokonania”, „ambitny”, „dostatnie życie”;

- wolnością wyboru, niezależnością myślenia i działania, kompetencją intelektualną: „,wolność”, „niezależny”, „odważny”, „obdarzony wyobraźnią”, „o szerokich horyzontach”, „uzdolniony”, „intelektualista”, „logiczny”;

- hedonizmem i zapotrzebowaniem na stymulację (ciekawe, przyjemne, urozmaicone życie): „,szczęście”, „pogodny”, „przyjemność”, ,ż̇ycie pełne wrażeń”, „świat piękna”.

\section{WYNIKI BADAŃ}

W prezentowanym badaniu starano się zdiagnozować, czy akceptowane jest szeroko rozumiane otwarcie kulturowe na Zachód, jeżeli zagraża ono naszej kulturze i tradycjom narodowym. Dokonując trzykrotnych pomiarów (rok 2003, 2008 i 2013) ustalono, jak postawy te zmieniają się w okresie, gdy były już zaawansowane przeobrażenia ustrojowe i Polska wstąpiła do Unii Europejskiej.

W każdym badaniu pozytywną rolę kultury i tradycji narodowych w kształtowaniu tożsamości społeczeństwa podkreślała większa część respondentów (por. ryc. 1.1). Odsetek studentów zajmujących takie stanowisko wynosił: 67,38\% (rok 2003), 56,20\% (rok 2008) i 65,22\% (rok 2013). Mniejsza część - kolejno: 32,62\%, 43,80\% i 34,78\% - była zwolennikami opcji przeciwnej: społeczeństwo powinno jak najszybciej dołączyć do Zachodu i zidentyfikować się z kulturą zachodnią. Stanowisko to zyskało na atrakcyjności (około 11\% respondentów) w roku 2008 w stosunku do roku 2003 ( $x 2$ = 9,23; p = 0,002). Dokonując analizy porównawczej wskaźników uzyskanych w roku 2008 i w roku 2013, zaobserwowano już jednak odwrotny kierunek zależności: stosunkowo większa liczba badanych (około 9\%) przejawiała troskę o status kultury i tradycji narodowych $\left(x^{2}=6,36 ; \mathrm{p}=0,012\right)$. Podobieństwem zatem cechowały się postawy wobec analizowanej kwestii, gdy pomiary były wykonywane przez 10 lat (rok 2003 i 2013).

Inne relacje między procentowymi wskaźnikami postaw stwierdzono analizując następną parę twierdzeń.

Uwidaczniają się różnice w wyborze twierdzeń między studentami diagnozowanymi w roku 2003 i 2008 (około 10\%; x2 = 14,18; p = 0,000) oraz między studentami diagnozowanymi w roku 2003 i 2013 (około 10\%; $\chi 2$ = 15,06; p = 0,000). W pierwszym badaniu - w porównaniu do dwóch następnych - większy odsetek 


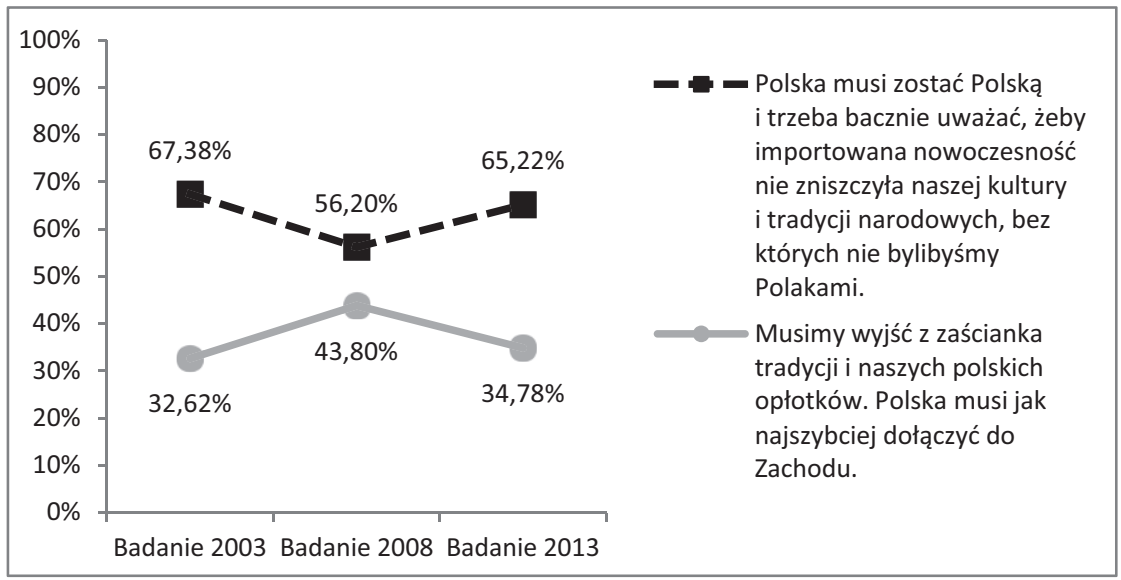

Rycina 1.1. Porównanie wyników badań z 2003, 2008 i 2013 roku: postawa A Źródło: Badania własne (wyniki badań z 2003 i 2008 roku zostały opublikowane we wcześniejszych pracach, Czerniawska, 2010, 2013).

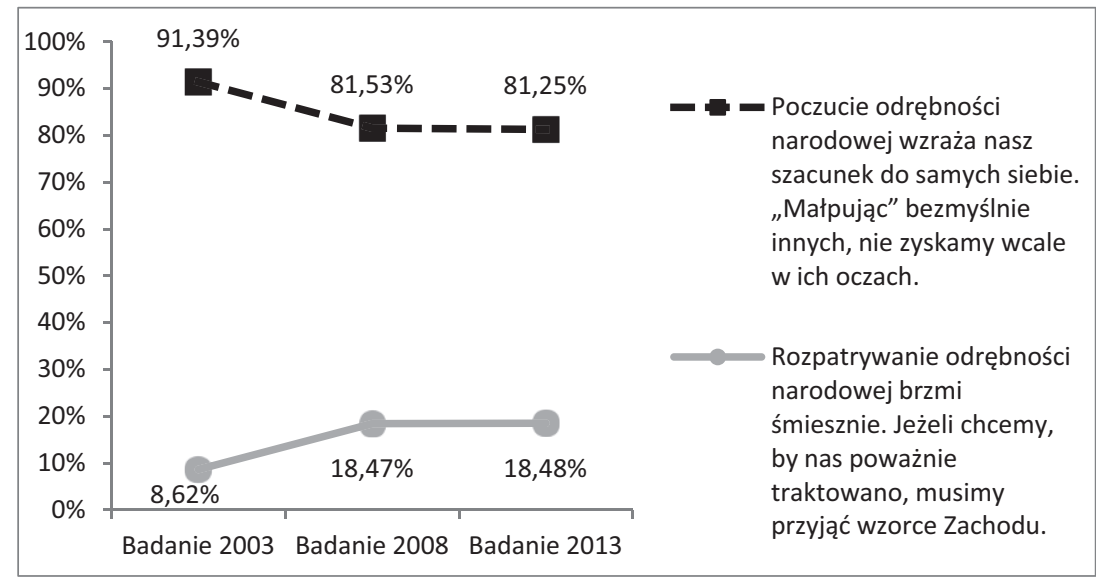

Rycina 1.2. Porównanie wyników badań z 2003, 2008 i 2013 roku: postawa B Źródło: Badania własne (wyniki badań z 2003 i 2008 roku zostały opublikowane we wcześniejszych pracach, Czerniawska, 2010, 2013). 
respondentów poczucie odrębności kulturowej uznawał za przejaw szacunku do samych siebie. Nie stwierdzono różnic dokonując analizy porównawczej danych uzyskanych w roku 2008 i 2013. Wskaźniki procentowe postaw obrazujących pozytywny stosunek do odrębności kulturowej były wysokie w każdej badanej grupie (wynosiły kolejno: 91,38\%, 81,53\% i 81,25\%) i znacznie przewyższające wskaźniki procentowe postaw wyrażających akceptację przyjęcia wzorców z Zachodu (wynosiły kolejno: 8,62\%, 18,47\% i 18,48\%).

W poddanej weryfikacji hipotezie założono, że w nowych warunkach ustrojowych na atrakcyjności zyskiwać będzie to, co identyfikowane jest jako kultura zachodnia. Większość studentów wykazywało jednak troskę o to, że przerwaniu może ulec międzypokoleniowy przekaz kulturowy, zaś formułowanie ideałów społecznych odbywać się będzie poza nurtem historycznych tradycji kraju. Wzrosły, co prawda, „prozachodnie” preferencje w zakresie wzorców kulturowych, ale odnotowano je tylko w przypadku porównania grup badanych w 2003 i 2008 roku. Bazując na danych uzyskanych w tych dwóch grupach można potwierdzić hipotezę 1. Porównanie grup diagnozowanych w 2008 i 2013 doprowadza do niespójnych wniosków: albo obniża się w percepcji badanych atrakcyjność wzorców kultury Zachodu (postawa A), albo nie ulegają one zmianie (postawa B). To z kolei nie pozwala przyjąć założeń zwerbalizowanych w hipotezie 1.

W następnej kolejności sprawdzono, czy wartości - ich zróżnicowanie preferencji w wymiarze „kolektywizm - indywidualizm” - ukierunkowują odmienny sposób myślenia o kulturze i tradycji własnego narodu. Wskaźniki preferencji wartości ostatecznych i instrumentalnych oraz wyniki analizy statystycznej przedstawione zostały w tabeli 1 . W prezentacji graficznej - rycina 2.1. i 2.2. - wartości uporządkowane są według różnicy w średnich rang między grupami, które wyodrębnione zostały ze względu na wybór opcji postawy (zabieg ten zastosowano w we wcześniejszych publikacjach, ale dotyczył on grup badawczych z roku 2003 i 2008, por. Czerniawska, 2010, 1013). Usytuowanie wartości na rysunkach dostarcza zatem ważnych informacji w analizie. I tak, w górnej części ryciny zlokalizowane są wartości, w przypadku których odnotowano największe zróżnicowanie międzygrupowe: $\mathrm{z}$ lewej strony znajdują się wartości wyżej preferowane przez studentów wybierających jedną opcję postawy, z prawej strony - wartości wyżej preferowane przez studentów wybierających drugą opcję postawy. W dolnej części ryciny umiejscowione są wartości, w przypadku których różnice te były najmniejsze (bądź w ogóle nie występowały). 
Tabela 2. Średnie rang wartości w grupach studentów różniących się wyborem opcji postawy oraz wyniki analizy statystycznej

\begin{tabular}{|c|c|c|c|c|c|c|c|c|c|}
\hline \multirow[b]{3}{*}{ o1 } & \multirow{3}{*}{$\begin{array}{c}\text { Wartości: } \\
\text { ostateczne o1-o18 } \\
\text { instrumentalne i1-i18 } \\
\text { Bezpieczeństwo narodowe }\end{array}$} & \multicolumn{8}{|c|}{ Średnie arytmetyczne rang wartości w grupach } \\
\hline & & \multirow{2}{*}{\multicolumn{2}{|c|}{$\begin{array}{r}\mathbf{A}_{\mathbf{1}} \\
11,67\end{array}$}} & \multicolumn{2}{|c|}{$\mathbf{A}_{2}$} & \multicolumn{2}{|c|}{$\mathbf{B}_{1}$} & \multicolumn{2}{|c|}{$\mathbf{B}_{2}$} \\
\hline & & & & 10,94 & $* *$ & 11,45 & & 11,17 & \\
\hline o2 & Bezpieczeństwo rodziny & 3,65 & & 2,86 & $* * * *$ & 3,19 & & 3,15 & \\
\hline o3 & Dojrzała miłość & 5,64 & & 6,05 & & 5,66 & & 5,94 & \\
\hline 04 & Dostatnie życie & 9,26 & $* * * *$ & 10,81 & & 8,31 & $* * * *$ & 10,58 & \\
\hline 05 & Mądrość & 6,59 & $* *$ & 7,09 & & 7,01 & & 6,88 & \\
\hline o6 & Poczucie dokonania & 10,73 & $* * * *$ & 11,61 & & 11,01 & & 11,32 & \\
\hline o7 & Poczucie własnej godności & 7,35 & & 7,57 & & 8,07 & & 7,38 & $*$ \\
\hline 08 & Pokój na świecie & 11,33 & & 10,54 & $* *$ & 12,08 & & 10,62 & $* * * *$ \\
\hline o9 & Prawdziwa przyjaźń & 7,56 & & 7,21 & & 7,87 & & 7,24 & \\
\hline 010 & Przyjemność & 11,97 & $* * *$ & 12,64 & & 11,28 & $* * * *$ & 12,59 & \\
\hline 011 & Równowaga wewnętrzna & 8,42 & & 8,13 & & 8,86 & & 8,12 & $*$ \\
\hline 012 & Równość & 11,20 & & 10,72 & $* *$ & 11,71 & & 10,75 & $* * *$ \\
\hline 013 & Szczęście & 6,20 & & 6,51 & & 5,48 & $* * * *$ & 6,56 & \\
\hline 014 & Świat piękna & 14,98 & & 14,41 & $* * *$ & 14,81 & & 14,59 & \\
\hline 015 & Uznanie społeczne & 12,26 & & 12,78 & & 11,34 & $* * * *$ & 12,82 & \\
\hline 016 & Wolność & 7,22 & & 7,42 & & 7,94 & & 7,24 & $* *$ \\
\hline 017 & Zbawienie & 11,61 & & 9,42 & $* * * *$ & 12,29 & & 9,87 & $* * * *$ \\
\hline o18 & Życie pełne wrażeń & 13,29 & $* * * *$ & 14,29 & & 12,77 & $* * * *$ & 14,13 & \\
\hline i1 & Ambitny & 7,94 & $* * *$ & 8,71 & & 7,43 & $* * *$ & 8,60 & \\
\hline i2 & Czysty & 10,66 & & 10,82 & & 9,86 & $* * *$ & 10,93 & \\
\hline i3 & Intelektualista & 8,32 & $* * * *$ & 9,99 & & 8,32 & $* * *$ & 9,55 & \\
\hline i4 & Kochający & 4,55 & & 4,21 & $*$ & 4,49 & & 4,31 & \\
\hline i5 & Logiczny & 10,69 & & 11,15 & & 11,09 & & 10,95 & \\
\hline i6 & Niezależny & 9,19 & $* * *$ & 10,22 & & 10,08 & & 9,78 & \\
\hline i7 & Obdarzony wyobraźnią & 10,83 & $* * *$ & 11,66 & & 11,10 & & 11,39 & \\
\hline i8 & Odpowiedzialny & 5,89 & & 5,38 & & 6,02 & & 5,49 & \\
\hline i9 & Odważny & 9,78 & & 9,97 & & 9,42 & & 9,99 & \\
\hline i10 & Opanowany & 10,61 & & 10,03 & $* *$ & 10,57 & & 10,19 & \\
\hline i11 & O szerokich horyzontach & 10,09 & $* * * *$ & 11,47 & & 11,53 & & 10,84 & \\
\hline $\mathrm{i} 12$ & Pogodny & 9,45 & & 9,24 & & 9,87 & & 9,21 & \\
\hline i13 & Pomocny & 8,50 & & 7,03 & $* * * *$ & 8,38 & & 7,44 & $* *$ \\
\hline
\end{tabular}




\begin{tabular}{|c|c|c|c|c|c|c|c|c|}
\hline \multirow{2}{*}{\multicolumn{2}{|c|}{$\begin{array}{c}\text { Wartości: } \\
\text { ostateczne o1-o18 } \\
\text { instrumentalne i1-i18 } \\
\end{array}$}} & \multicolumn{7}{|c|}{ Średnie arytmetyczne rang wartości w grupach } \\
\hline & & \multirow{2}{*}{\multicolumn{2}{|c|}{$\frac{\mathbf{A}_{\mathbf{1}}}{15,37}$}} & \multicolumn{2}{|c|}{$\mathbf{A}_{2}$} & \multirow{2}{*}{$\begin{array}{r}\mathbf{B}_{1} \\
14,49\end{array}$} & \multicolumn{2}{|c|}{$\mathbf{B}_{2}$} \\
\hline i14 & Posłuszny & & & 14,72 & $* * *$ & & 15,06 & \\
\hline i15 & Uczciwy & 5,98 & & 5,15 & $* * * *$ & 6,13 & 5,33 & $* *$ \\
\hline i16 & Uprzejmy & 10,07 & & 8,98 & $* * * *$ & 9,24 & 9,42 & \\
\hline i17 & Uzdolniony & 11,89 & $* *$ & 12,58 & & 12,19 & 12,35 & \\
\hline i18 & Wybaczający & 11,12 & & 9,55 & $* * * *$ & 10,92 & 10,00 & $* *$ \\
\hline
\end{tabular}

o1 - o18 - średnie rang osiemnastu wartości ostatecznych (łącznie dla trzech grup badawczych); i1 - i18 - średnie rang osiemnastu wartości instrumentalnych (łącznie dla trzech grup badawczych); Ranga «1» oznacza najwyższą preferencję wartości, ranga «18» - najniższą preferencję wartości; $\mathrm{A}_{1}$ - studenci wybierający opcję „1” w postawie A; $\mathrm{B}_{1}$ - studenci wybierający opcję „1” w postawie B; $\mathrm{A}_{2}$ - studenci wybierający opcję „1” w postawie A; $\mathrm{B}_{2}$ - studenci wybierający opcję „1” w postawie B. Wyniki analizy statystycznej testem Wilcoxona dla dwóch prób niezależnych między grupami $\mathrm{A}_{1}$ i $\mathrm{A}_{2}$ oraz między grupami $\mathrm{B}_{1}$ i $\mathrm{B}_{2}$

$* \mathrm{p}<0,1 \quad * * \mathrm{p}<0,05 \quad * * * \mathrm{p}<0,01 \quad * * * * \mathrm{p}<0,001$

Źródło: Badanie własne.

\section{POSTAWA A}

Uwzględniając wyniki analizy statystycznej przedstawionej w tabeli 2 (postawa A) i informacje zaprezentowane na rycinie 2.1, można zaobserwować zróżnicowanie preferencji licznych wartości w zależności od wyboru opcji postawy.

W grupie studentów eksponujących znaczenie kultury i tradycji własnego narodu odnotowano wyższe wskaźniki preferencji szeregu wartości kolektywistycznych (por. prawa strona ryciny): „zbawienie”, „wybaczający”, „pomocny”, „uprzejmy”, „uczciwy”, „bezpieczeństwo rodziny”, „pokój na świecie”, „bezpieczeństwo narodowe”, „posłuszny”, „opanowany”, „równość” i „kochający”. Wyższe wskaźniki preferencji uzyskała także indywidualistyczna wartość „świat piękna”. Odnoszą się one do takich obszarów jak: poszanowanie religii, ochrona dobra innych ludzi, bezpieczeństwo, harmonia interpersonalna i intrapersonalna. Studenci akceptujący zachodnie wzory kulturowe cenili wyżej wartości poznawcze, związane z sukcesem osobistym (w tym materialnym), statusem społecznym i prestiżem, niezależnością i hedonizmem (por. lewa strona ryciny): „intelektualista, „dostanie życie”, „o szerokich horyzontach”, „niezależny”, „życie pełne wrażeń”, „poczucie dokonania”, „obdarzony wyobraźnią”, „ambitny”, „uzdolniony” „przyjemność” oraz ceniła wartość kolektywistyczną „mądrość”. 


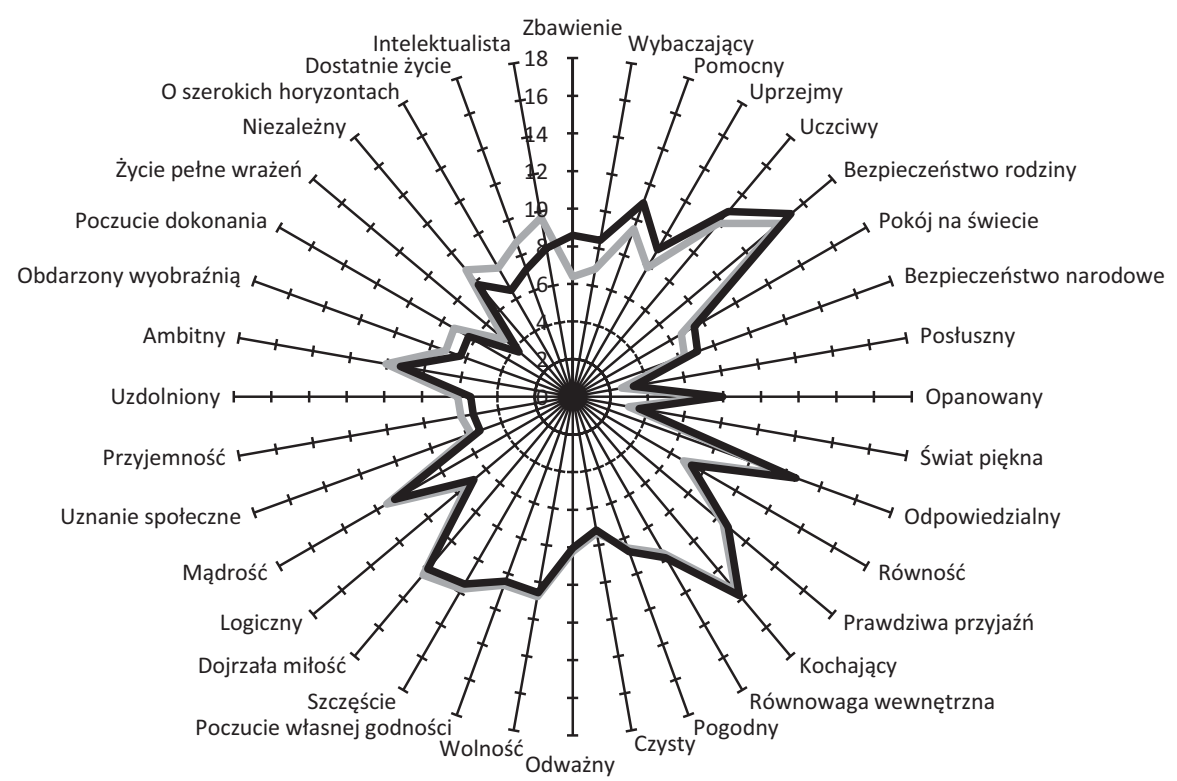

Musimy wyjść z zaścianka tradycji i naszych polskich opłotków. Polska musi jak najszybciej dołączyć do Zachodu.

Polska musi zostać Polską i trzeba bacznie uważać, żeby importowana nowoczesność nie zniszczyła naszej kultury i tradycji narodowych, bez których nie bylibyśmy Polakami.

Rycina 2.1. Zróżnicowanie systemów wartości ostatecznych i instrumentalnych w zależności od wyboru opcji w postawie A

Źródło: Badania własne.

\section{POSTAWA B}

W przypadku analizy zróżnicowań preferencji wartości odnoszących się do postawy B należy stwierdzić, że studenci akcentujący znaczenie odrębności narodowej cenili wyżej wartości kolektywistyczne, zaś studenci opowiadający się za przyjęciem wzorców z Zachodu - wartości indywidualistyczne (tab. 2; ryc. 2.2.)

Pierwsza ze wskazanych grup ceniła relatywnie wyżej wartości związane z poszanowaniem religii, ochroną dobra innych oraz harmonią intrapersonalną: „zbawienie”, „pokój na świecie”, „równość”, „pomocny”, „wybaczający”, „uczciwy” i „równowaga wewnętrzna” (por. prawa strona ryciny). Stosunkowo wyższym uznaniem cieszyły się też dwie wartości indywidualistyczne: „,wolność” i „poczucie własnej godności”. Druga grupa cechowała się wyższymi wskaźnikami preferencji wartości związanych sukcesem osobistym i statusem społecznym oraz wartości hedonistyczne i poznawcze: „dostatnie życie, „uznanie społeczne”, 


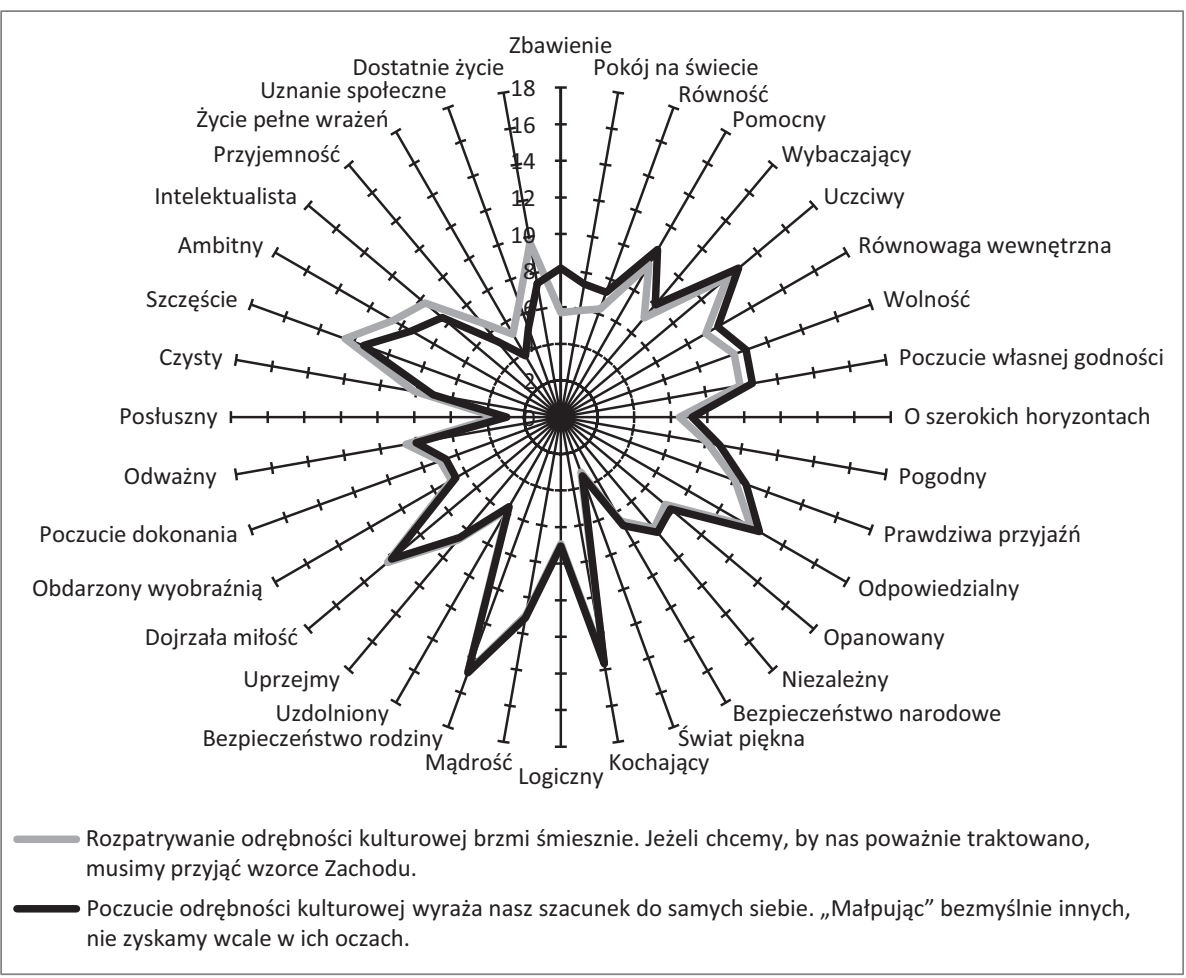

Rycina 2.2. Zróżnicowanie systemów wartości ostatecznych i instrumentalnych w zależności od wyboru opcji w postawie B

Źródło: Badania własne.

„życie pełne wrażeń”, „przyjemność”, „intelektualista”, „ambitny”, „szczęście” oraz wartość kolektywistyczną „czysty” (por. lewa strona ryciny).

Uzyskane wyniki badań pozwalają na potwierdzenie założeń przyjętych w hipotezie 2: pozytywne postawy wobec kultury narodowej i tradycji wiążą się z wyższą preferencją wartości kolektywistycznych, akceptacja integracji w warstwie kulturowej z Zachodem - wyższą preferencją wartości indywidualistycznych. Sporadycznie pojawiają się wartości, które są niezgodne z opisaną zależnością. 


\section{PODSUMOWANIE I DYSKUSJA}

W niniejszym badaniu podjęto próbę odpowiedzi na pytanie, czy kultura i tradycje narodowe tracą na znaczeniu? Okazało się, że studenci diagnozowani w roku 2008 w porównaniu ze studentami diagnozowanymi w roku 2003 wskazywali częściej na konieczność kulturowego otwarcia na Zachód (postawa A i B). Był to okres szczególny, z uwagi na fakt wstąpienia Polski do Unii Europejskiej w 2004 roku i uruchomienie procesów integracyjnych. Rozbudzone zostały różnego rodzaju nadzieje związane z funkcjonowaniem w ramach szerszej niż narodowa wspólnoty, ale jednocześnie wzmagały się dyskusje odnośnie do statusu polskiej kultury i jej roli na forum europejskim. Znamienne jest to, że w następnym badaniu - przeprowadzonym w roku 2013 (a więc wtedy, gdy procesy integracyjne były zaawansowane) - nie odnotowano już wzrostu akceptacji wzorów kultury Zachodu (postawa B), a w przypadku jednej z postaw (postawa A) zaobserwowano zmiany w kierunku przeciwnym: stosunkowo większa liczba respondentów - niż w roku 2008 - doceniła znaczenie kultury i tradycji własnego narodu. W interpretacji opisanych zależności odwołano się do wyników sondażu CBOS (Roguska, 2013). Okazało się, że między rokiem 2003 i 2008 zwiększył się procentowy wskaźnik zwolenników integracji europejskiej z około 60\% do 80-88\%. Od roku 2008 (w którym odnotowano jeden z najwyższych wskaźników) poparcie dla integracji zaczęło się obniżać i w roku 2013 było 72-78\% zwolenników tego procesu. Można więc zauważyć paralelne zmiany w ustosunkowaniu się do integracji europejskiej (badania CBOS) i ustosunkowaniu się do wzorców kultury zachodniej (badania własne). Sceptycyzm wobec procesów integracji wzmaga koncentrację na tym, co ważne w określeniu tożsamości narodu.

W następnej kolejności starano się odpowiedzieć na pytanie, dlaczego ludzie mają odmienny stosunek do kultury i tradycji narodowych. Wyjaśnienia tych różnic poszukiwano w specyfice mentalności, a bardziej konkretnie - w syndromie „kolektywizm - indywidualizm”, który zoperacjonalizowany został na podstawie wskaźników preferencji wartości. Wyższe wskaźniki akceptacji wartości kolektywistycznych ujawniły się wśród tych badanych, którzy eksponowali znaczenie dziedzictwa kulturowego, wyższe wskaźniki akceptacji wartości indywidualistycznych - wśród tych badanych, którzy opowiadają się za kulturowym otwarciem na Zachód. Szczególnie diagnostyczną okazała się wartość religijna „zbawienie”, w przypadku której odnotowano największą różnicę rang w zależności od wyboru opcji postawy. Stosunek do religii i religijność wydają się najsilniej zakorzenione w tradycji. Siła tej tradycji skłania do stosowania gotowych scenariuszy osadzonych zarówno w religii, jak i w kulturze z tą religią związanej. 
W roku 2018 planowany jest następny etap badań (czwarty), którego celem będzie m.in. zdiagnozowanie stosunku do kultury i tradycji narodowych. Nie wiadomo, w jakim stopniu rosnący wśród Polaków sceptycyzm wobec procesu pogłębiania integracji europejskiej (Boguska, 2013) przełoży się na uzyskane wyniki. Niezależnie jednak od tego, jaka część badanych opowie się za kulturowym otwarciem na Zachód, to ta część właśnie będzie lokowała relatywnie wyżej w swoim systemie wartości indywidualistyczne. Ci, którzy będą akceptować tradycjonalizm w sferze kulturowej i akcentować ważność poczucia tożsamości narodowej, będą cechowali się systemem wartości zorientowanym kolektywistycznie. Dzieje się tak dlatego, że spójne z wartościami postawy (i inne elementy systemu przekonań) pozwalają tworzyć w umyśle jednostki koherentną wizję świata. Założenie na temat powiązań pomiędzy różnego rodzaju przekonaniami przyjęte było w teorii Rokeacha $(1973,1980)$. Zdaniem tego autora, przekonania nie występują w izolacji, lecz tworzą względnie spójny i uporządkowany hierarchicznie system. Najwyższe piętro stanowią wartości i one też odgrywają najważniejszą rolę (w innych teoriach zgodności poznawczej koncentrowano się z reguły na relacjach pomiędzy postawami oraz postawami i zachowaniem). Stopień powiązań między przekonaniami może być jednak różny u różnych ludzi (np. istotną zmienną różnicującą jest poziom wykształcenia) i jest uzależniony od dziedziny, której dotyczą. W przypadku opisywanych w niniejszym badaniu studentów (a więc osób o określonej charakterystyce rozwoju struktur poznawczych) takie strukturalne więzy są obecne: od systemu wartości, a zwłaszcza od tego, w jakim stopniu cenią oni wartości zorientowane na Ja, a w jakim - na innych ludzi, uzależnione jest to, jak spostrzegają kulturę i tradycje narodowe.

Z metodologicznego punktu widzenia należy podkreślić fakt, że badanie systemów wartości umożliwia uzyskanie informacji o nastawieniach indywidualistycznych vs kolektywistycznych i wnioskowanie na temat tego, w jakim społeczeństwie chcieliby ludzie funkcjonować. Z perspektywy pedagogicznej sformułować można wniosek, że eksponowanie określonych wartości w procesie wychowawczym ukierunkowuje stosunek człowieka do wspólnoty, więzów społecznych, przeszłości i spuścizny kulturowej.

\section{Bibliografia:}

Bokszański, Z. (2007). Indywidualizm a zmiana społeczna. Polacy wobec nowoczesności - raport z badań. Warszawa: Wydawnictwo Naukowe PWN.

Brzozowski, P. (1989). Skala Wartości (SW). Polska adaptacja Value Survey M. Rokeacha. Warszawa: Wydział Psychologii Uniwersytetu Warszawskiego. 
Cybal-Michalska, A. (2006). Tożsamość młodzieży w perspektywie globalnego świata. Poznań: Wydawnictwo Naukowe UAM.

Czerniawska, M. (2010). Zmiany wartości i postaw młodzieży w okresie przeobrażeń ustrojowych. Kolektywizm versus indywidualizm. Studium interdyscyplinarne. Białystok: Oficyna Wydawnicza Politechniki Białostockiej.

Czerniawska, M. (2013). Stosunek do kultury i tradycji narodowej oraz jego aksjologiczne uwarunkowania. Ekonomia i Zarządzanie, 5 (2), s. 23-37.

Daab, W.Z. (1990). Indywidualizm-kolektywizm jako orientacje społeczno-polityczne. W: J. Reykowski, K. Skarżyńska, M. Ziółkowski (red.), Orientacje społeczne jako element mentalności (s. 121-137). Poznań: Nakom.

Jarymowicz, M. (1999). O godzeniu wody z ogniem: związki kolektywizmu z indywidualizmem. W: B. Wojciszke, M. Jarymowicz (red.), Psychologia rozumienia zjawisk społecznych (s. 121-152). Warszawa: Wydawnictwo Naukowe PWN.

Kłoskowska, A. (1996). Kultury narodowe u korzeni. Warszawa: Wydawnictwo Naukowe PWN.

Lewicka, M. (2005). „Polacy są wielkim i dumnym narodem”, czyli nasz portret (wielce) zróżnicowany. W: M. Drogosz (red.), Jak Polacy przegrywają. Jak Polacy wygrywają (s. 5-34). Gdańsk: GWP.

Maio, G.R., Olsen, J.M. (1998). Values as truisms: Evidence and implications. Journal of Personality and Social Psychology, 74, s. 294-311. DOI: 10.1037/0022-3514.74.2.294.

Marody, M., Giza-Poleszczuk, A. (2004). Przemiany więzi społecznych: zarys teorii zmiany społecznej. Warszawa: Scholar.

Miluska, J. (2005). Indywidualizm i kolektywizm polskich studentów w okresie transformacji systemowej. W: U. Jakubowska, K. Skarżyńska (red.), Demokracja w Polsce - doświadczenie zmian (s. 131-146). Warszawa: Wydawnictwo SWPS Academica.

Reykowski, J. (1992). Kolektywizm i indywidualizm jako kategorie opisu zmian społecznych i mentalności. Przegląd Psychologiczny, 35, s. 147-171.

Reykowski, J. (1993) (red.). Wartości i postawy Polaków a zmiany systemowe. Szkice z psychologii politycznej. Warszawa: Wydawnictwo Instytutu Psychologii PAN.

Roguska, B. (oprac.) (2013). Stosunek Polaków do integracji europejskiej. Komunikat z badań CBOS. Pobrane z: www.cbos.pl/SPISKOM.POL/2013/K_072_13.PDF.

Rokeach, M. (1973). The nature of human values. New York: Free Press.

Rokeach, M. (1980). Some unresolved issues in theories of beliefs, attitudes, and values. W: H.E. Howe Jr., M.M. Page (red.), Nebraska Symposium on Motivations 1979 (s. 261-304). Lincoln: University of Nebraska Press.

Seligman, C., Katz, A.N. (1996). The dynamics of value systems. W: C. Seligman, J.M. Olson, M.P. Zanna (red.), The psychology of values: The Ontario Symposium, t. 8 (s. 53-75). Mahwah, New Jersey: Lawrence Erlbaum Associate.

Schwartz, S.H. (1996). Value priorities and behavior: Applying a theory of integrated value systems. W: C. Seligman, J.M. Olson, M.P. Zanna (red.), The psychology of values: The Ontario Symposium, t. 8 (s. 1-24). Mahwah, New Jersey: Lawrence Erlbaum Associates, Inc.

Schwartz, S.H. (2003). Mapping and interpreting cultural differences around the world. 
W: H. Vinken, J. Soeters, P. Ester (red.), Comparing culture, dimensions of culture in comparative perspective (s. 43-73). Leiden: Brill.

Schwartz S.H., Bardi, A. (1997). Influences of adaptation to communist rule on value priorities in Eastern Europe. Political Psychology, 18, s. 385-410. DOI: 10.1111/0162-895X.00062.

Triandis, H.C. (1996). Kultura subiektywna. W: A.S.R. Manstead, M. Hewstone (red.), Encyklopedia Blackwella. Psychologia społeczna (s. 235-237). Warszawa: Wydawnictwo Jacek Santorski \& CO. 